\title{
Biosynthesis and Role in Virulence of the Histone Deacetylase Inhibitor Depudecin from Alternaria brassicicola
}

\author{
Wanessa D. Wight, ${ }^{1}$ Kwang-Hyung Kim, ${ }^{2}$ Christopher B. Lawrence, ${ }^{2}$ and Jonathan D. Walton ${ }^{1}$ \\ ${ }^{1}$ Department of Energy - Plant Research Laboratory, Michigan State University, East Lansing, MI 48824, U.S.A.; ${ }^{2}$ Virginia \\ Bioinformatics Institute and Department of Biological Sciences, Virginia Tech, Blacksburg, VA 24061, U.S.A.
}

Submitted 8 April 2009. Accepted 25 May 2009.

\begin{abstract}
Depudecin, an eleven-carbon linear polyketide made by the pathogenic fungus Alternaria brassicicola, is an inhibitor of histone deacetylase (HDAC). A chemically unrelated HDAC inhibitor, HC toxin, was earlier shown to be a major virulence factor in the interaction between Cochliobolus carbonum and its host, maize. In order to test whether depudecin is also a virulence factor for $\boldsymbol{A}$. brassicicola, we identified the genes for depudecin biosynthesis and created depudecinminus mutants. The depudecin gene cluster contains six genes $(D E P 1$ to $D E P 6)$, which are predicted to encode a polyketide synthase ( $A b P K S 9$ or $D E P 5)$, a transcription factor (DEP6), two monooxygenases (DEP2 and DEP4), a transporter of the major facilitator superfamily (DEP3), and one protein of unknown function $(D E P 1)$. The involvement in depudecin production of $D E P 2, D E P 4, D E P 5$, and DEP6 was demonstrated by targeted gene disruption. DEP6 is required for expression of $D E P 1$ through $D E P 5$ but not the immediate flanking genes, thus defining a coregulated depudecin biosynthetic cluster. The genes flanking the depudecin gene cluster but not the cluster itself are conserved in the same order in the related fungi Stagonospora nodorum and Pyrenophora tritici-repentis. Depudecin-minus mutants have a small $(10 \%)$ but statistically significant reduction in virulence on cabbage (Brassica oleracea) but not on Arabidopsis. The role of depudecin in virulence is, therefore, less dramatic than that of $\mathrm{HC}$ toxin.
\end{abstract}

Host-selective toxins (HST) are positive agents of specificity and virulence in a number of plant-disease interactions (Friesen et al. 2008; Walton 1996; Walton and Panaccione 1993). All known HST are made by fungi, and most of them are small, secondary metabolites. HC toxin, a cyclic tetrapeptide made by Cochliobolus carbonum, is a critical determinant of virulence in the interaction between the pathogen and its host, maize. Isolates of $C$. carbonum that synthesize $\mathrm{HC}$ toxin are extremely virulent on maize homozygous recessive at the nuclear $H M 1$ and $H M 2$ loci, killing plants in a few days (Sindhu et al. 2008; Walton 2006). HMI encodes HC-toxin

W. Wight and K.-H. Kim contributed equally to this work.

Corresponding authors: J. Walton; E-mail: walton@msu.edu; and C. Lawrence; E-mail: lawrence@vbi.vt.edu

Nucleotide sequence data is available in the GenBank database under accession number FJ977165.

* The $\boldsymbol{e}$-Xtra logo stands for "electronic extra" and indicates that Figure 9 appears in color and a supplemental table is published online. reductase, which detoxifies $\mathrm{HC}$ toxin by reducing an essential carbonyl group in HC toxin (Johal and Briggs 1992; Meeley et al. 1992; Multani et al. 1998). HC toxin is an inhibitor of histone deacetylases (HDAC) of the type I (RPD3/HDAl-like) and type II (HD2, plant-specific) classes but not of the type III (SIR2-like, sirtuin) class (Brosch et al. 1995; Hollender and Liu 2009). HC toxin has been shown to inhibit type I HDAC in maize, protozoans, yeast, and mammals, both in vivo and in vitro, and has been used as a specific HDAC inhibitor in numerous studies (Brosch et al. 1995; Darkin-Rattray et al. 1996; Deubzer et al. 2008; Joung et al. 2004). There is no evidence that $\mathrm{HC}$ toxin and chemically related compounds have any other sites of action.

Earlier studies on the role of HC toxin in plant pathogenesis raise the question of the role of HDAC in plant disease-why does inhibition of HDAC facilitate the development of disease, i.e., what is the role of HDAC in disease resistance? Attempting to further our understanding of HDAC and disease is complicated by several factors. First, there are multiple sensitive HDAC in maize and other plants. Maize has 14 and Arabidopsis has 16 HDAC genes of the HC toxin-sensitive classes (RPD3, HDA1, and HD2) (Gendler et al. 2008). Second, all of the core histones are subject to reversible acetylation, and each has multiple lysine residues capable of being acetylated. HC toxin affects acetylation of multiple core histones in maize, especially H3 and H4 (Ransom and Walton 1997). There are, thus, many possible permutations of histone acetylation/deacetylation, especially when combined with multiple possible permutations of acetylation-dependent methylation, which can lead to different physiological outcomes (Jenuwein et al. 2001). Third, many nonhistone proteins have now been shown to be regulated by reversible acetylation, including tubulin, cell-cycle regulators, transcription factors, DNA helicases, heat-shock factors, and HDAC themselves (Brandl et al. 2009; Westerheide et al. 2009). Therefore, there are many possible relevant targets of $\mathrm{HC}$ toxin, each, in turn, with multiple possible substrates.

Reversible histone acetylation is involved in many cellular processes (Brandl et al. 2009; Haberland et al. 2009), and as a result, HDAC mutations in plants are pleiotropic. Mutational and inhibition studies indicate that HDAC control the expression of numerous plant genes and are involved in the regulation of many processes, such as embryo and flower development, the jasmonic acid (JA) and ethylene pathways, light responses, senescence, nucleolar dominance, silencing of transgenes and transposons, Agrobacterium transformability, leaf polarity, abscisic acid and abiotic stress responses, and roothair density (Hollender and Liu 2009). In cereals, hda101 mutants of maize have pleiotropic effects on development and 
gene expression (Rossi et al. 2007). Overexpression of a rice HDAC gene causes changes in plant growth and architecture (Jang et al. 2003).

In regard to the role of histone acetylation in plant pathogenesis, HDA19 expression in Arabidopsis is induced by infection with the pathogen Alternaria brassicicola, and overexpression of HDA19 causes enhanced resistance and upregulation of ethylene and JA-induced pathogenesis-related (PR) proteins (Zhou et al. 2005). However, in light of the multiple developmental abnormalities of HDA19 mutants, it is not clear if HDA19 has a primary or secondary role in disease resistance (Tian and Chen 2001; Wu et al. 2000, 2003). Mutants in HUB1, a gene encoding a histone $\mathrm{H} 2 \mathrm{~B}$ mono-ubiquitinating enzyme, have earlier flowering, thinner cell walls, and increased susceptibility to A. brassicicola and Botrytis cinerea (Dhawan et al. 2009).

Another connection between histone acetylation and disease response comes from the finding that HDA6 of Arabidopsis interacts with COI1, an F-box protein required for JA signaling (Devoto et al. 2002; Thines et al. 2007). This is consistent with the known importance of JA in response to A. brassicicola (discussed below) and with transcription profiling experiments suggesting a link between COI1-regulated genes and resistance to $A$. brassicicola (van Wees et al. 2003). JA induces expression of HDA6 and HDA19 but not HDA5, HDA8, HDA9, HDA14, or HD2A (Zhou et al. 2005).

HDA19 interacts with WRKY38 and WRKY62, which are negative regulators of defense induced by salicylic acid or Pseudomonas syringae infection in an NPRl-dependent manner (Kim et al. 2008). Overexpression of HDA19 enhances resistance and mutation enhances susceptibility; that is, HDA19 appears to act as a positive regulator of defense. HDA19 might work through ERF1, a gene that integrates JA and ethylene pathways, because HDA19 overexpression upregulates ERF1 (Zhou et al. 2005).

HDAC and their target proteins can be both positive and negative regulators of gene expression (Brandl et al. 2009). If HDAC are necessary for induction of defense genes, then by inhibiting HDAC, HC toxin might suppress expression of those genes (Brosch et al. 1995). This model is consistent with the studies on HDA19 in the Pseudomonas syringae-Arabidopsis pathosystem (Kim et al. 2008) but does not exclude other models, e.g., that HDAC repress a negative regulator of defense. There are several additional major uncertainties, such as whether HDAC could have a different role in dicotyledons versus cereals such as maize and to what extent the role of HDAC might be affected by the known differences in defense signaling pathways in response to bacterial biotrophic pathogens such as Pseudomonas syringae as opposed to necrotrophs such as $C$. carbonum and A. brassicicola.

In order to expand our understanding of the role of HDAC in defense, we have considered the A. brassicicola-Arabidopsis pathosystem. A. brassicicola causes black spot of most cultivated Brassica species, including broccoli, cabbage, canola, and mustard. Many species in the genus Alternaria make hostselective toxins (Walton 1996). Although A. brassicicola is a weak pathogen on wild-type Arabidopsis (Kagan and Hammerschmidt 2002), it causes significant disease on pad3 (phytoalexin-deficient) and DELLA mutants (Navarro et al.

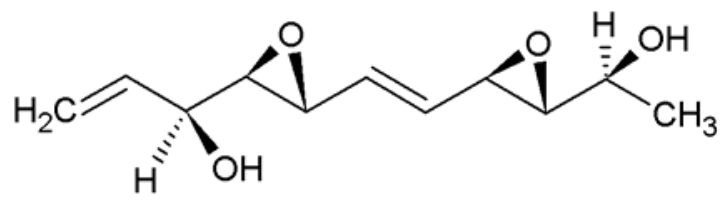

Fig. 1. Structure of the polyketide depudecin (Tanaka et al. 2000).
2008; Thomma et al. 1999). Its genome has been sequenced and it is genetically tractable (Cho et al. 2006). Transcriptional changes during infection have been profiled in the fungus (Cramer and Lawrence 2004) and in the host (Narasuka et al. 2003; Schenk et al. 2003; van Wees et al. 2003). Plant factors that modulate reaction to $A$. brassicicola include JA, gibberellins acting through the JA pathway, BOS1 (encoding an R2R3MYB transcription factor), BOS2, BOS3, BOS4, RLM3 (encoding a TIR-domain protein), and lipase (Mengiste et al. 2003; Navarro et al. 2008; Oh et al. 2005; Staal et al. 2008; Veronese et al. 2004).

A critical attribute of $A$. brassicicola from the point of view of elucidating the role of reversible histone acetylation in defense is that it makes an HDAC inhibitor called depudecin (Kwon et al. 1998; Matsumoto et al. 1992). Depudecin is a small linear polyketide (Fig. 1) (Tanaka et al. 2000). Depudecin is antiparasitic and antiangiogenic and, like $\mathrm{HC}$ toxin, causes detransformation of oncogene-transformed mammalian cells and inhibits HDAC activity in vitro and in vivo (Kwon et al. 1998, 2003; Matsumoto et al. 1992; Oikawa et al. 1995). If depudecin is a virulence factor for A. brassicicola on Arabidopsis, one could exploit the genetic resources of both partners to address the role of HDAC in disease resistance. Here, we report the identification and characterization of the gene cluster responsible for depudecin biosynthesis in A. brassicicola and the disease phenotype of depudecin-minus strains. Although depudecin does contribute to virulence of this fungus, the effect is much less dramatic than the role of $\mathrm{HC}$ toxin in the $C$. carbonum-maize interaction.

\section{RESULTS}

AbPKS9 encodes the depudecin polyketide synthase.

We identified nine genes encoding putative polyketide synthases (PKS), designated AbPKS1 through AbPKS9, in the

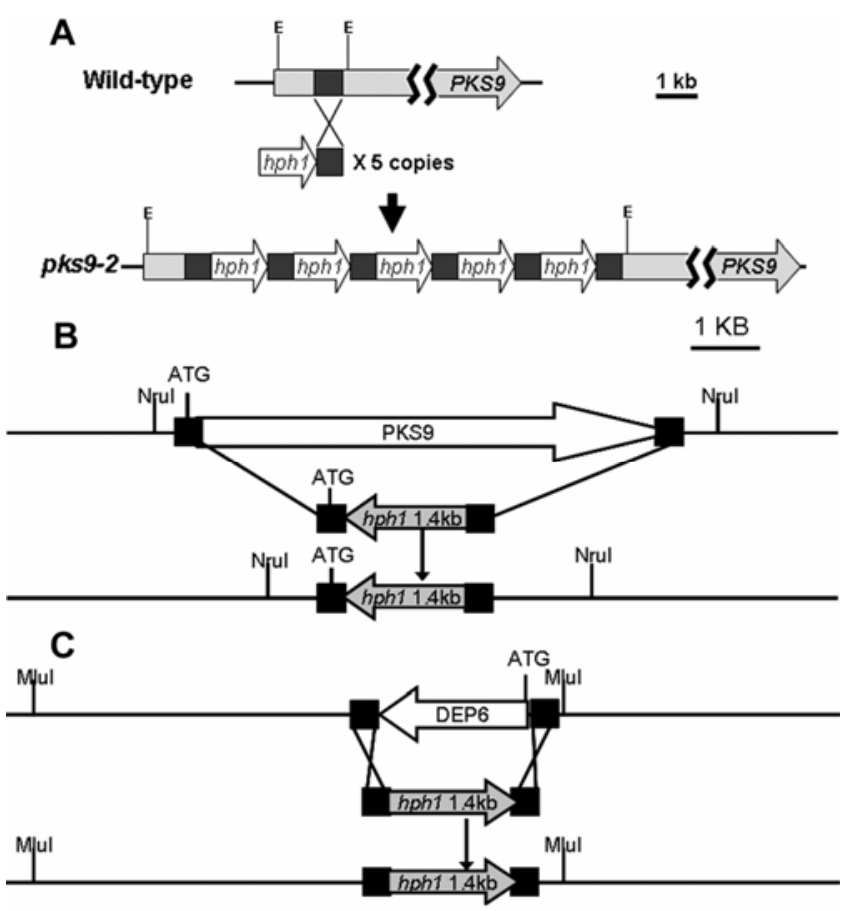

Fig. 2. Strategies for disrupting depudecin biosynthetic genes. A, Linear minimal element (LME) strategy and predicted outcome (shown for $p k s 9-2$ in ATCC 96836). B, Gene replacement strategy and predicted outcome for DEP5 (AbPKS9) in MUCL 20297. C, Gene replacement strategy and predicted outcome for DEP6. hphl designates the gene encoding hygromycin phosphotransferase, and E designates EcoRI sites. 
genome of A. brassicicola. Disruption mutants for each PKS gene were generated in American Type Culture Collection (ATCC) strain 96836, using the linear minimal element (LME) method (Cho et al. 2006). The strategies and expected results for homologous integration at AbPKS9 are shown in Figure 2A
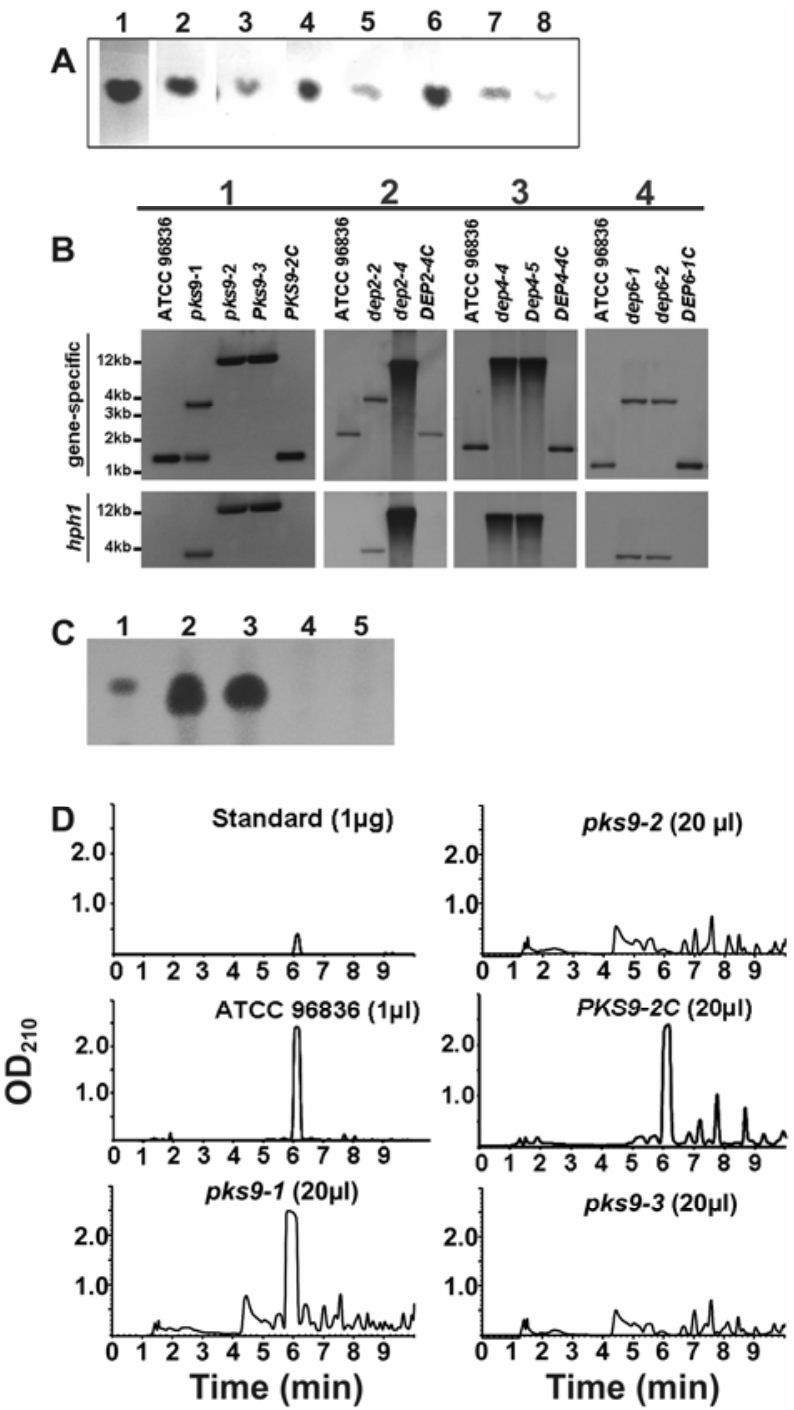

Fig. 3. Characterization of depudecin mutants and complemented strains in Alternaria brassicicola ATCC 96836. A, Lanes 1 through 8, thin-layer chromatography (TLC) analysis of culture filtrates of Abpks1 to Abpks8 mutants. Depudecin was detected with an epoxide-specific reagent. B, DNA blot analysis of transformants. In each pair of panels labeled 1 through 4 , the upper panel was hybridized with a gene-specific probe and the lower panel with a fragment of the hphl gene. Panel 1 shows three independent Abpks9 transformants ( $p k s 9-1, p k s 9-2$, and $p k s 9-3$ ) and a complemented strain (PKS9-2C) of mutant $p k s 9-2$. DNA was cut with EcoRI. Panel 2 shows two independent mutants (dep2-2 and dep2-4) and a complemented strain (DEP2-4C) of DEP2. DNA was cut with PstI. Panel 3 shows two independent mutants (dep4-4 and dep4-5) and a complemented strain (DEP4-4C) of DEP4. DNA was cut with BamHI. Panel 4 shows two independent mutants (dep6-1 and dep6-2) and a complemented strain (DEP6-1C) of DEP6. DNA was cut with XhoI and BamHI. C, TLC analysis of ATCC 96836 wild type, pks9-1 ectopic mutant, and pks9-2 and pks $9-3$ disruption mutants. Lanes $1,5 \mu \mathrm{g}$ of depudecin standard; 2, $10 \mu \mathrm{l}$ of extract of ATCC 96836; 3, $10 \mu \mathrm{l}$ of pks9-1 ectopic extract; 4, $10 \mu \mathrm{l}$ of pks9-2 mutant; and 5, $10 \mu \mathrm{l}$ of pks9-3 mutant. D, High-performance liquid chromatography analysis of transformants. Note that 20 -fold more culture filtrate was injected of the four transformants than the wild type. Depudecin was eluted from the column at approximately 6 min and was detected at $210 \mathrm{~nm}$. The identities of the compound eluted at $6 \mathrm{~min}$ and the compound with the same $\mathrm{R}_{\mathrm{f}}$ (retention factor) on TLC were confirmed as authentic depudecin by mass spectrometry (data not shown). and B. Mutants of $A b P K S 1$ through $A b P K S 8$ still produce depudecin (Fig. 3A, and data not shown). The phenotypes of these mutants are currently being evaluated.

Of three transformants obtained using LME targeted to $A b P K S 9$, DNA blotting indicated that two are knockout mutants and one is an ectopic transformant (Fig. 3B, panel 1). Both the wild type and the pks9-1 strains contain a $1.6-\mathrm{kb}$ $E c o$ RI fragment hybridizing to $A b P K S 9$, and strain $p k s 9-1$ has a $3.6-\mathrm{kb}$ band hybridizing to $h p h 1$, which together indicate that pks9-1 is an ectopic transformant. In both pks9-2 and pks9-3 transformants, the $1.6-\mathrm{kb}$ band is replaced by an approximately $12-\mathrm{kb}$ band hybridizing to $A b P K S 9$ (Fig. 3B, panel 1), consistent with homologous tandem integration of five copies of the construct (Fig. 2). The 1.6-kb wild-type band is restored in the complemented mutant PKS9-2C (Fig. 3B, panel 1). Based on thin-layer chromatography (TLC) and high-performance liquid chromatography (HPLC) analysis, neither of the knockout mutants ( $p k s 9-2$ and pks9-3) produces depudecin, whereas the ectopic transformant ( $p k s 9-1)$ and the complemented strain do (Fig. 3C and D).

Additional mutants of AbPKS9 were made by double-crossover gene replacement in a different strain of $A$. brassicicola, Mycothèque Université Catholique de Louvain, Belgium (MUCL) 20297. Two independent mutants of AbPKS9, called pks9-4 and pks9-5, were verified by DNA blotting (Fig. 4A and B). Neither produces depudecin (Fig. 4C and D). Together, these results indicate that $A b P K S 9$ encodes the PKS responsible for depudecin biosynthesis. In light of subsequent characterization of the depudecin biosynthetic cluster, $A b P K S 9$ was renamed DEP5 (discussed below).
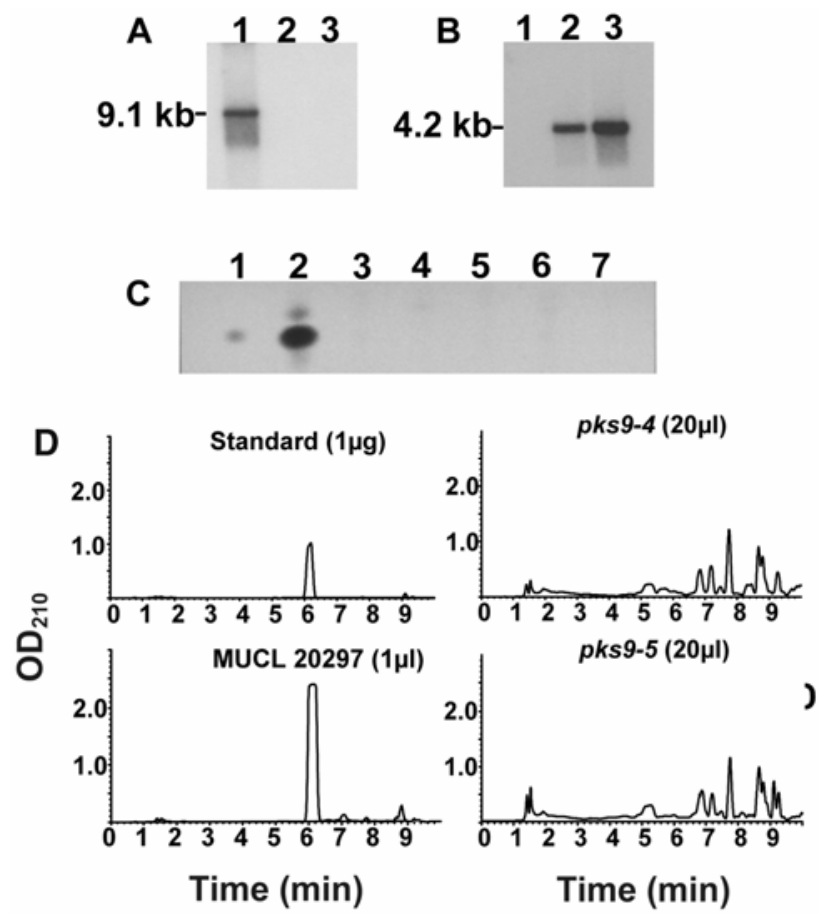

Fig. 4. Characterization of depudecin mutants in MUCL 20297. A, DNA blot analysis of wild type (lane 1) and two replacement mutants (lanes 2, pks9-4 and 3, pks9-5) probed with the deleted fragment of AbPKS9 (DEP5). B, DNA blot analysis of the same three strains probed with a fragment of the hphl gene. C, Thin-layer chromatography analysis of crude extracts of wild type and pks $9-4$ and $p k s 9-5$ replacement mutants. Lanes $1,5 \mu \mathrm{g}$ of depudecin standard; $2,10 \mu \mathrm{l}$ of wild type; $3,10 \mu \mathrm{l}$ of pks9-4; 4, $10 \mu \mathrm{l}$ of pks9-5; 5, $10 \mu \mathrm{l}$ of dep6-3; 6, $10 \mu \mathrm{l}$ of dep6-4; and 7, $10 \mu \mathrm{l}$ of dep6-5. D, High-performance liquid chromatography analysis of wild type and replacement mutants. Note that 20 -fold more of the two mutants than the wild type was injected. 
The depudecin biosynthetic cluster.

The protein coding regions in $72 \mathrm{~kb}$ of genomic DNA surrounding AbPKS9 were predicted with FGENESH using the Alternaria-specific training matrix. The genes adjacent to PKS9 are predicted to encode two monooxygenases, a membrane transporter of the major facilitator superfamily (MFS), and a transcription factor, all of which could have a plausible role in depudecin biosynthesis and regulation. The two monooxygenases and the transcription factor were chosen for mutational analysis. Disruption of the putative MFS transporter was not attempted because genes of this class are often necessary for self-protection, in which case a mutant would be lethal (Pitkin et al. 1996).

The LME strategy was used to construct mutants of the two monooxygenases (DEP2 and DEP4). Two independent mutants of each gene were obtained (dep2-2, dep2-4, dep 4-4, and
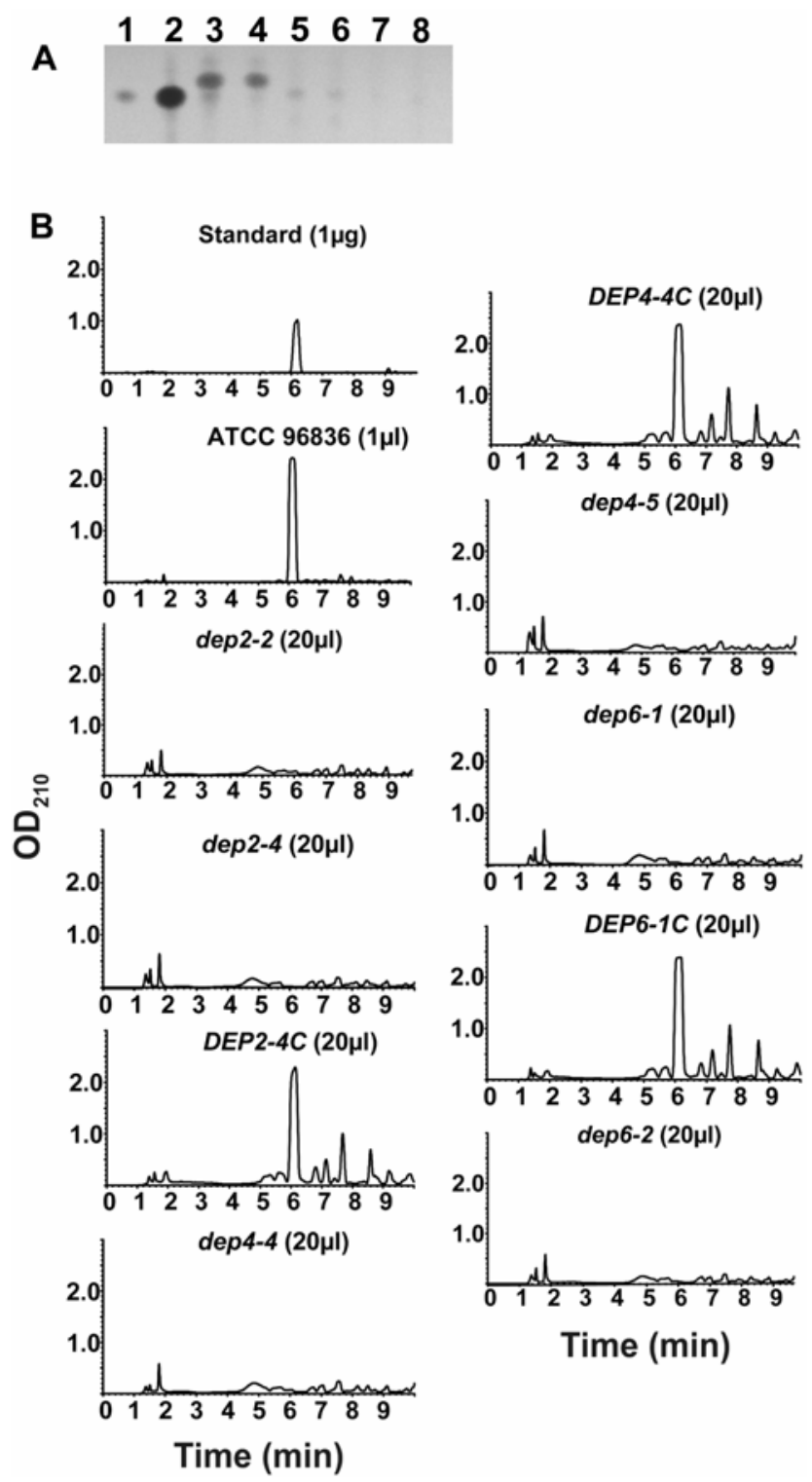

Fig. 5. Mutational characterization of genes in the depudecin cluster. A, Thin-layer chromatography analysis of depudecin production. Crude extract $(10 \mu \mathrm{l})$ was applied to each lane. Lanes 1 , depudecin standard; 2 , wildtype ATCC 96836; 3, dep2-2; 4, dep2-4; 5, dep4-4; 6, dep4-5; 7, dep6-1; and 8, dep 6-2. B, High-performance liquid chromatography analysis of wild type, depudecin mutants (dep2-2, dep2-4, dep4-4, dep4-5, dep6-1, and dep6-2), and complemented mutants (DEP2-4C, DEP4-4C, and DEP6-1C). Depudecin is the peak eluted at approximately $6 \mathrm{~min}$. dep4-5) (Fig. 3B, panels 2 and 3). Both dep2 mutants fail to produce depudecin as judged by TLC and HPLC but do produce smaller amounts of an epoxide-containing metabolite of slightly higher retention factor $\left(\mathrm{R}_{\mathrm{f}}\right)$ than native depudecin (Fig. $5 \mathrm{~A}$, lanes 3 and 4). This compound is not depudecin as judged by HPLC (Fig. 5B). Both dep4 mutants also produce a trace of an epoxide-containing compound of the same $R_{f}$ as native depudecin (Fig. 5A, lanes 5 and 6). Again however, this is not native depudecin as judged by HPLC, in which no compound of the same retention time as depudecin is seen (Fig. 5B). Complementation of the dep2-4 and dep4-4 mutants (DEP2$4 C$ and DEP4-4C) restores depudecin synthesis (Fig. 5B). The mutants have no other distinguishable phenotypes (growth, color, morphology, and sporulation). These results indicate that the two putative monooxygenase genes are also required for and dedicated to depudecin biosynthesis.

Two engineered mutants of the putative transcription factor gene, called DEP6, made with the LME method (dep6-1 and dep6-2) do not produce depudecin (Figs. 3B, panel 4, and 5A, lanes 7 and 8 , and $\mathrm{B}$ ). Complementation of dep6-1 restores depudecin production (DEP6-1C) (Fig. 5B). Three independent dep6 mutants (dep6-3, dep6-4, and dep6-5), constructed using double-crossover gene replacement in MUC 20297, also fail to synthesize depudecin (Figs. 4C and 6). dep6 mutants have no discernible phenotype other than loss of depudecin production. These results indicate that DEP6, like AbPKS9, $D E P 2$, and $D E P 4$, is required for and dedicated to the biosynthesis of depudecin.

\section{$D E P 6$ regulates the depudecin cluster.}

DEP6 is required for biosynthesis of depudecin (Figs. 4C, 5, and 6). Its sequence shows some similarity to known fungal transcription factors (discussed below). Therefore, it might be
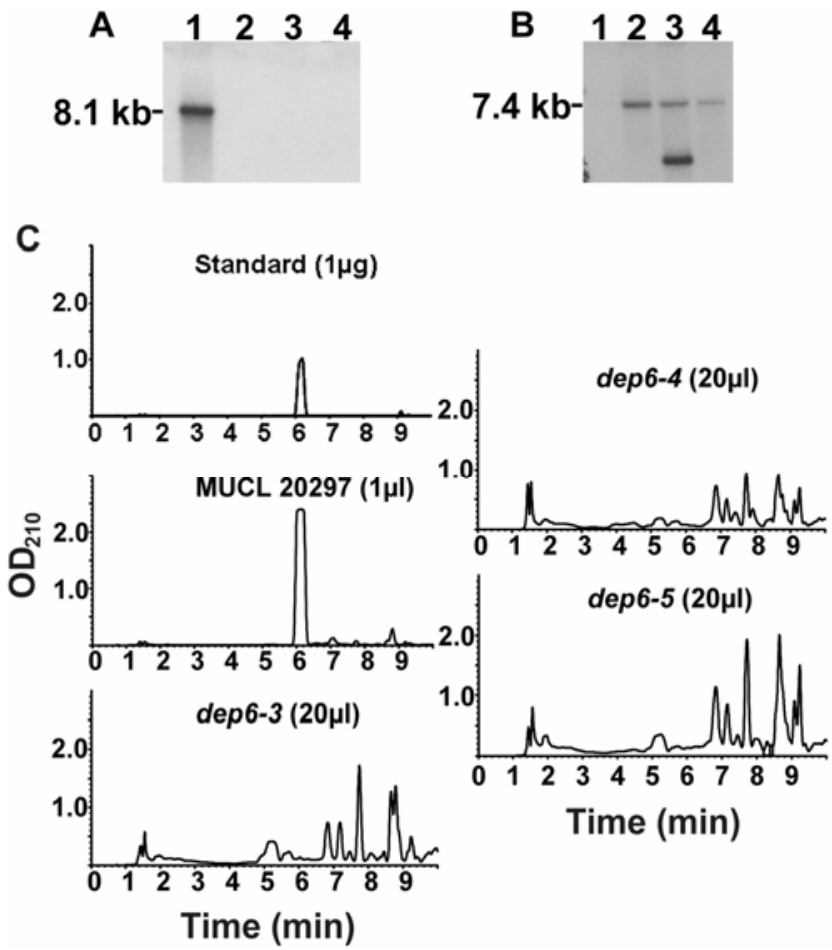

Fig. 6. Analysis of dep6 mutants in MUCL 20297. A, DNA blot analysis of wild type (lane 1) and three mutants (lanes 2, dep6-3; 3, dep6-4; and 4, dep6-5). Blot was probed with a fragment of DEP6. B, DNA blot analysis of the same strains except probed with $h p h 1$. dep6-4 shows multiple bands hybridizing to $h p h 1$, apparently due to a multiple integration event or to an additional ectopic integration. C, High-performance liquid chromatography analysis of depudecin production by wild type and the mutant strains. 
a pathway-specific regulator of the expression of the genes involved in depudecin biosynthesis and could be used to help define the depudecin cluster. In order to test this, expression of the putative depudecin cluster genes was analyzed by RNA blotting. As shown in Figure 7, RNA expression of $D E P 2$ and $D E P 4$ (the monooxygenases), DEP3 (the MFS transporter), DEP5 (AbPKS9), and DEP6 itself are dependent on DEP6. Furthermore, expression of another gene upstream of $D E P 2$, called DEP1, is also dependent on DEP6 (Fig. 7). On this basis, $D E P 1$ is part of the depudecin gene cluster. Expression of the genes immediately upstream of DEP1 and downstream of DEP6 (genes 4 and 11) are not affected in the dep6 strain and, therefore, are not part of the coregulated gene cluster (Fig. 7).

\section{Genes of the depudecin cluster.}

Reverse transcriptase polymerase chain reaction (RT-PCR) and rapid amplification of cDNA ends (RACE) were used to determine the structures and protein products of $D E P 1$ through $D E P 6 . D E P 1$ has no introns. Dep1, the protein encoded by $D E P 1$, has 369 amino acids and a molecular mass of $40.3 \mathrm{kDa}$. Regulation by DEP6 (Fig. 7) and synteny analysis (discussed below) suggest a role in depudecin biosynthesis. It has no detectable conserved domains. The best match by BLASTP in GenBank is to a predicted protein (CIMG_02399) from Coccidioides immitis (score 303, expect 2e-80, 48\% amino acid identity). The second best hit, a predicted protein from Talaromyces stipitatus, is considerably less similar (score 132, expect 5e-29, 28\% identity). Several additional hypothetical proteins from ascomycetes give weaker scores $(>1 \mathrm{e}-22)$. There are no strong orthologs in other members of the family Pleosporaceae (Fig. 8). None of the putative orthologs has a known function.

$D E P 2$ has three introns. Its predicted product has 528 amino acids $(59.1 \mathrm{kDa})$. BLASTP results indicate that it has conserved domains corresponding to the pyridine nucleotide-disulfide oxidoreductase superfamily. It has an FAD-binding domain (pfam family 01494). Dep2 is also a member of COG0654 $(\mathrm{UbiH})$ containing 2-polyprenyl-6-methoxyphenol 4-monooxygenase and related FAD-dependent oxidoreductases. The best BLASTP hit against the nonredundant (NR) database is to a hypothetical protein (CIMG_01450) from Coccidioides immitis (expect score 1e-135, 53\% identity). Dep2 is also similar (expect scores <1e-50) to a number of hypothetical FADdependent monooxygenases from other ascomycetes. By BLASTP against SwissProt, Dep2 shows weak amino-acid similarity to salicylate monooxygenase (EC 1.14.13.2) and zeaxanthin epoxidase (EC 1.14.12.4). These monooxygenases are all in class A (van Berkel et al. 2006). A number of monooxygenases of this class have been shown to be involved in secondary metabolite biosynthesis. For example, atmM of Aspergillus flavus and paxM of Penicillium paxilli are predicted monooxygenases involved in the biosynthesis of the indole-diterpenes aflatrem and paxilline, respectively. These compounds contain hydroxyl groups and aflatrem contains an epoxide (Young et al. 2001; Zhang et al. 2004). In the biosynthesis of depudecin, Dep2 might be responsible for the epoxidations or hydroxylations of depudecin (Fig. 1). The novel product made in the dep 2 mutants might be depudecin with one less hydroxyl or epoxide or both (Fig. 5A).

$D E P 3$ has eight exons. Its product is 564 amino acids $(60.1$ kDa). DEP3 encodes a membrane transporter of the MFS. MFS genes are found in many fungal secondary metabolite clusters and are presumed either to be responsible for exporting secondary metabolites, to provide self-protection, or both (Pitkin et al. 1996).

DEP4 has four exons and its product is 581 amino acids in length $(66.0 \mathrm{kDa})$. Its best hit is CIMG_02397 of Coccidioides immitis (expect score $0.0,66 \%$ identity), followed by a large

\section{$1 \mathrm{~kb}$}

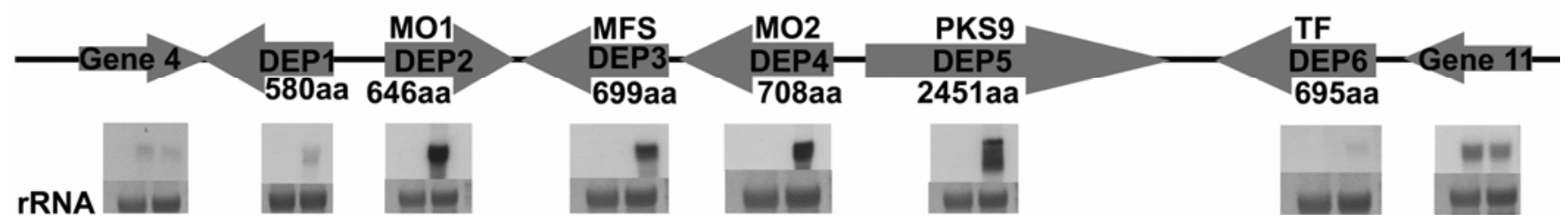

Fig. 7. The depudecin gene cluster of Alternaria brassicicola ATCC 96836. Arrows indicate the directions of transcription. The sizes of the mature proteins are indicated in amino acids (aa). RNA analysis of each gene in the dep6 mutant are shown under the map. In each panel, the upper two lanes show RNA hybridization to the indicated gene. Wild type is on the right and the dep6 mutant on the left. The two lower lanes show the major ribosomal band stained on the blot with methylene blue. MO1 = monooxygenase 1 , MFS = major facilitator superfamily transporter, MO2 = monooxygenase 2 , PKS9 = polyketide synthase 9, and TF = transcription factor. "Gene 4" and "gene 11" refer to two flanking genes that are not regulated by dep6. The depudecin gene cluster ( $D E P 1$ through DEPO) has been submitted to GenBank and assigned accession number FJ977165.

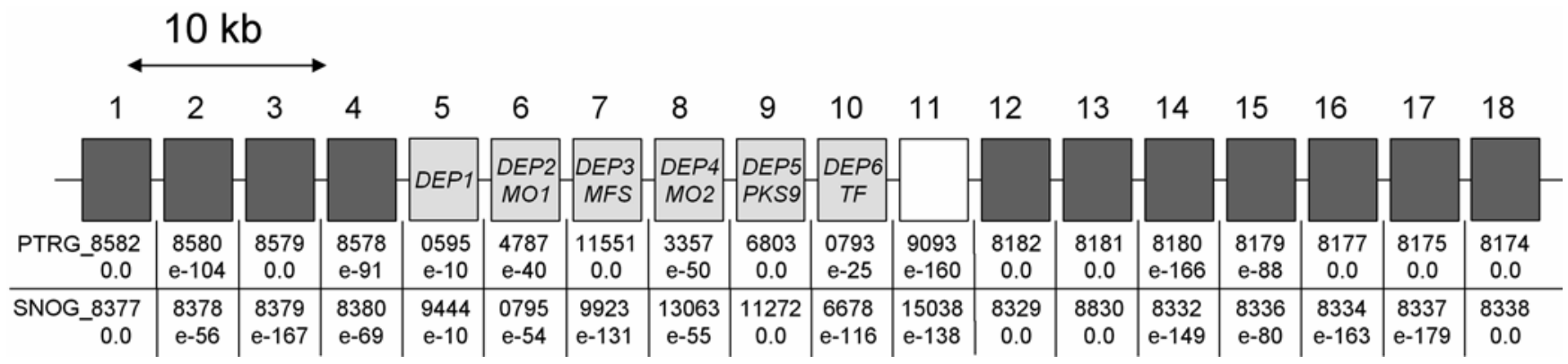

Fig. 8. Synteny between Alternaria brassicicola, Pyrenophora tritici-repentis, and Stagonospora nodorum in the depudecin cluster region. The gene numbers indicate the best BLASTP hit of each A. brassicicola protein in the genomes of P. tritici-repentis (PTRG) or S. nodorum (SNOG). The numbers underneath the gene numbers are the expect scores of the BLASTP hit. Syntenic genes are shown in dark gray, the genes of the depudecin cluster in light gray, and the "anomalous" gene 11 in white. 
number of hypothetical proteins in other ascomycetes. Conserved domains include COG2072 (TrkA, predicted flavoprotein involved in $\mathrm{K}^{+}$transport) and pfam00743 (flavin-binding monooxygenase). Although $D E P 2$ and $D E P 4$ are both predicted to encode monooxygenases, they are of different classes. Whereas Dep2 is in class A, Dep4 is in class B (van Berkel et al. 2006). Dep4 is related to cyclohexanone 1,2-monooxygenase (EC 1.14.13.22), 4-hydroxyacetophenone monooxygenase, and dimethylaniline monooxygenase. Like monooxygenases of class A, enzymes related to Dep4 can catalyze epoxidations (Colonna et al. 2002; van Berkel et al. 2006).

DEP5 (also known as AbPKS9 and as AB01916 in the recently released annotation of $A$. brassicicola at the Department of Energy Joint Genome Institute and at the Virginia Bioinformatics Institute) has five exons, and its product has 2,376 amino acids (259 kDa). Dep5 is a PKS, the central enzyme in depudecin biosynthesis. Of characterized PKS in the SwissProt database, Dep5 shows high overall amino-acid similarity to the lovastatin nonaketide synthase of Aspergillus terreus (Hendrickson et al. 1999). Dep5 is a type I reducing PKS with modules for ketoacyl synthase, acyltransferase, enoyl reductase, and terminal acyl carrier protein. There is also probably a dehydratase module.

$D E P 6$ has four exons and encodes a 646 -amino acid protein $(72.6 \mathrm{kDa})$. At its amino terminus, Dep6 contains a GAL4-like $\mathrm{Zn}_{2} \mathrm{Cys}_{6}$ binuclear cluster DNA-binding motif typical of fungal transcription factors. The best hit against the GenBank NR database is to SNOG_06678, a putative transcription factor in Stagonospora nodorum. The dependence of expression of $D E P 1$ through DEP5 on DEP6 is consistent with it encoding a pathway-specific transcription factor (Pedley and Walton 2001).

\section{A related gene cluster in Coccidioides immitis?}

The best BLASTP hits against the GenBank NR database for three of the depudecin cluster genes are proteins from Coccidioides immitis, even though GenBank contains many complete genomes of fungi more closely related to A. brassicicola (which is a member of the class Dothidiomycetes) than Coccidioides immitis (a member of the class Eurotiomycetes). Furthermore, the two best hits to the products of $D E P 1$ and DEP4 are Coccidioides immitis proteins closely linked to each other (CIMG_02399 and CIMG_02397, respectively). This raises the possibility that Coccidioides immitis has a gene cluster that is related to the depudecin cluster of A. brassicicola.

To explore this possibility further, additional BLASTP queries were performed, specifically against the genome of strain RS of Coccidioides immitis. The best match of Dep1 to any protein in the GenBank NR database is CIMG_02399 (discussed above). Dep3, encoding the MFS transporter, has numerous very strong hits in the NR database. However, the third best hit in GenBank and the best hit within Coccidioides immitis is CIMG_02396, which is now reannotated as CIMG_10938 (score 676, expect 0.0, identity 63\%). The best hit of Dep4 (monooxygenase) to any protein in the database is CIMG_02397 (score 769, expect 0.0, 66\% identity), which is also clustered with CIMG_02399.

PKS genes are common in fungi, and Dep5 (AbPks9) aligns with more than 50 proteins in the NR database with expect scores of 0.0. However, the fourth best hit of Dep5 against any protein is CIMG_02398 (score 2,390, expect 0.0, identity $52 \%$ ), which is clustered with the Coccidioides immitis orthologs of Dep1, Dep3, and Dep4. DEP2 and DEP6 do not continue the same pattern of clustering in Coccidioides immitis. The best match to Dep2 of any protein in the GenBank NR database is clearly also a Coccidioides immitis protein (CIMG_01450), but this is not clustered with the others. Fi- nally, the best hit of Dep6 in Coccidioides immitis is CIMG_10246, which has relatively poor similarity (score 103, expect $8 \mathrm{e}-22,24 \%$ identity).

In conclusion, four of the six genes of the depudecin cluster (DEP1, DEP3, DEP4, and DEP5) have as their best or among their best BLASTP hits four clustered genes in Coccidioides immitis (CIMG_2399, CIMG_2396, CIMG_2397, and CIMG_2398, respectively). This suggests that Coccidioides immitis has a gene cluster that is evolutionarily or functionally related to the depudecin cluster of A. brassicicola and raises the possibility that Coccidioides immitis makes a secondary metabolite that is chemically related to depudecin.

\section{Synteny of the depudecin cluster region \\ between $A$. brassicicola and \\ other members of the family Pleosporaceae.}

The predicted protein sequences flanking the depudecin cluster and the experimentally deduced proteins for $D E P 1$ through DEP6 were used to search the genomes of $S$. nodorum (Phaeosphaeria nodorum) and Pyrenophora tritici-repentis, which also belong to the class Dothideomycetes in the family Pleosporaceae. The four contiguous genes on the left flank of the depudecin cluster of $A$. brassicicola (Fig. 8, numbered 1 through 4) are contiguous in $P$. tritici-repentis and $S$. nodorum. The seven genes on the right side (genes 12 through 18) are also contiguous in all three fungi, although there is one local rearrangement in S. nodorum (inversion of SNOG_8336 and SNOG_8334) (Fig. 8). In both $P$. tritici-repentis and $S$. nodorum, the syntenic regions on the right and on the left are linked on the same supercontig but are not contiguous, i.e., there is a 396-gene gap in $P$. tritici-repentis and a 51-gene gap in $S$. nodorum between the left and right flanks. The closest hits to the depudecin genes themselves are scattered throughout the genomes of $P$. tritici-repentis and $S$. nodorum, representing other members of the same gene families (i.e., other PKS, MFS transporters, monooxygenases, etc.). There is no evidence for a gene cluster similar to the depudecin cluster in either $S$. nodorum or P. tritici-repentis.

These results indicate that the genomes of these three fungi are syntenous in the region surrounding the depudecin cluster but not the cluster itself. The depudecin cluster thus appears as an indel of approximately $25 \mathrm{~kb}$ in the genomes of $A$. brassicicola, S. nodorum, and P. tritici-repentis (Fig. 8). These results also support the conclusion drawn from analysis of the dep6 mutant that DEP1 through DEP6 constitute the depudecin gene cluster (Fig. 7). In this regard, gene 11 is an anomaly; it is neither regulated by DEP6 (Fig 7) nor is it syntenic with $P$. tritici-repentis and $S$. nodorum (Fig. 8). It is unlikely to be involved in depudecin biosynthesis because it is predicted to encode an $\alpha-1,3$-mannosyltransferase. This gene is a single copy in $P$. tritici-repentis and $S$. nodorum. One possible explanation for how this situation arose is that the presence of gene 11 is related to the indel event, i.e., it moved by chance with the cluster to its present location in the genome of $\mathrm{A}$. brassicicola, either from elsewhere in the genome or from another organism.

\section{Depudecin contributes to virulence on cabbage.}

Virulence of the wild type, two dep5 (pks9) mutants, an ectopic insertion mutant (which had wild-type production of depudecin), and a complemented mutant of DEP5 were compared on Brassica oleracea (green cabbage) leaves (Fig. 9). We observed a small but statistically significant $(P<0.01)$ reduction of approximately $10 \%$ in lesion size between wildtype and mutant strains (Fig. 9B). Depudecin is thus a minor virulence factor of $A$. brassicicola on cabbage. No statistically significant difference in virulence among the strains could be 
seen on Arabidopsis; however, even the pad3 mutant of Arabidopsis is more resistant to A. brassicicola than cultivated Brassica species, and detection of statistically significant changes in disease development may require much larger experimental sample sizes (Fig. 9C).

Mutants of the other depudecin cluster genes (dep2, dep4, and dep6) similarly showed no to slight reduction in virulence on cabbage and Arabidopsis (data not shown).

\section{DISCUSSION}

In this study we have identified a gene cluster involved in depudecin biosynthesis and have constructed multiple depudecin-minus strains of $A$. brassicicola. The depudecin cluster appears to comprise six genes, four of which we have shown by gene disruption to be required for depudecin biosynthesis. We cannot exclude that additional, unclustered genes are also required for depudecin biosynthesis. With the exception of $D E P 1$, the genes of the depudecin cluster have plausible roles in depudecin biosynthesis based on our knowledge of similar genes in other secondary metabolite pathways. DEP6, a putative transcription factor, is a positive regulator of the other genes of the cluster.

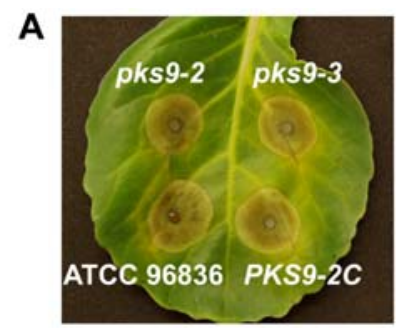

B

C
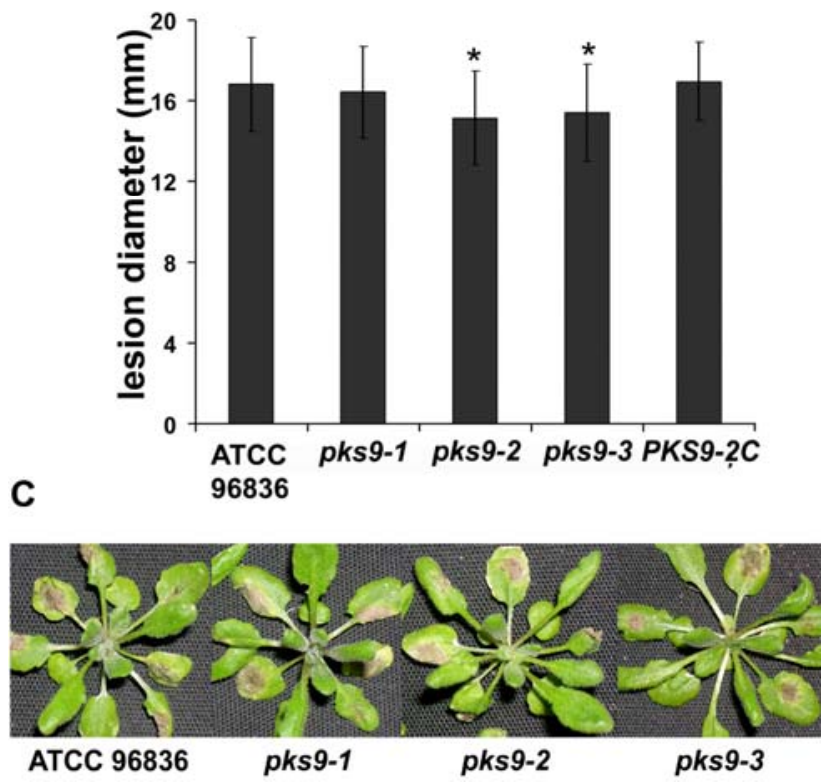

Fig. 9. Virulence analysis of Alternaria brassicicola dep5 (AbPKS9) mutants. A, Conidial suspension (10 $\mu \mathrm{l}$ of $2 \times 10^{4}$ conidia per milliliter) of ATCC 96836 wild type, two mutants ( $p k s 9-2$ and $p k s 9-3$ ), or a complemented strain ( $P K S 9-2 C$ ) were inoculated on green cabbage leaves. After inoculation (5 days), disease severity was calculated based on the lesion diameter. B, Quantitation of virulence. Column heights and error bars represent average and standard deviation, respectively, of four independent experiments, each experiment measuring at least 15 lesions. Stars indicate lesion diameters statistically significant $(P<0.01)$ from the others. $p k s 9-1$ is an ectopic transformant. C, Virulence of the ectopic transformant and two mutants on Arabidopsis pad3 plants.
Based on the pathogenicity assays, it appears that, while depudecin does play a minor role in virulence of $A$. brassicicola on cabbage, it is not a major virulence factor like $\mathrm{HC}$ toxin is for $C$. carbonum on maize. It was not possible to detect a statistically significant effect of depudecin on virulence on Arabidopsis pad3 plants.

There are several possible reasons why HC toxin but not depudecin is a strong virulence factor in their respective pathosystems. One possibility is that depudecin is not made in sufficiently high concentrations or penetrates insufficiently well to effectively inhibit HDAC during infection of cabbage or Arabidopsis. Compared with $\mathrm{HC}$ toxin, depudecin is a relatively weak HDAC inhibitor; whereas Aeo-containing cyclic peptides such as HC toxin cause half-maximal inhibition of in vitro $\mathrm{HDAC}$ activity at $<10 \mathrm{nM}$, depudecin is active only at approximately $50 \mu \mathrm{M}$ (Deubzer et al. 2008; Kwon et al. 1998; Monneret 2005).

Another possible explanation is that HDAC inhibition is an effective virulence strategy against grasses but not against other plants, including Arabidopsis (Sindhu et al. 2008). That is, HDAC might be required for defense against pathogens in some plants but not others. Despite many lines of data suggesting that HDAC have at least an indirect role in defense signaling in Arabidopsis, none of the evidence is as strong as that from the $C$. carbonum-maize pathosystem (Devoto et al. 2002; Dhawan et al. 2009; Kim et al. 2008; Thines et al. 2007; Walton 2006; Zhou et al. 2005). A possibly relevant consideration in this regard is the apparent specialization of the genera Alternaria and Cochliobolus. Although both make a number of host-selective toxins, Alternaria spp. tend to pathogenize dicotyledonous plants, whereas Cochliobolus spp. are specialized on cereals (Walton 1996). It is possible that defense in cereals differs fundamentally from other plants in the involvement of histone acetylation.

A third possible explanation for our results is that A. brassicicola makes additional HDAC inhibitors that mask the loss of depudecin production. In addition to at least five known cyclic tetrapeptide inhibitors related to $\mathrm{HC}$ toxin, there are a number of other natural products that are HDAC inhibitors (Monneret 2005; Walton 2006). Depudecin itself is known to be made by two fungi other than A. brassicicola (Amnuaykanjanasin et al. 2005; Tanaka et al. 2000). If A. brassicicola makes additional HDAC inhibitors, the mutant strains generated in this study will be useful for finding them.

\section{MATERIALS AND METHODS}

Fungal growth and depudecin analysis.

A. brassicicola ATCC 96836 and MUCL 20297 were maintained on potato dextrose agar (PDA) (BD Difco, Sparks, MD, U.S.A.) or V8-juice agar. For depudecin production, the fungus was grown in still culture in 1-liter flasks containing 125 $\mathrm{ml}$ of potato dextrose broth (PDB; Difco) for 7 to 10 days. The cultures were filtered through Whatman \#1 paper and were extracted twice with equal volumes of dichloromethane. The dichloromethane fractions were evaporated under vacuum at $40^{\circ} \mathrm{C}$ and were redissolved in $3 \mathrm{ml}$ of methanol. After concentration under vacuum, the residue was dissolved in 100 $\mu \mathrm{l}$ of methanol. This crude extract was used for both TLC and HPLC. Depudecin standard was obtained from Sigma-Aldrich (St. Louis) and was dissolved in methanol at $1 \mathrm{mg} / \mathrm{ml}$.

For TLC, crude extract ( $10 \mu \mathrm{l})$ was spotted onto $250-\mu \mathrm{m}$ silica plates with adsorbent strip (Whatman). Plates were developed in 1:1 acetone/dichloromethane. Depudecin was detected using an epoxide-specific reagent (Hammock et al. 1974).

For HPLC, $20 \mu \mathrm{l}$ of extract was combined with $60 \mu \mathrm{l}$ of acetonitrile and $20 \mu \mathrm{l}$ of sterile distilled water. The sample was 
injected onto a $\mathrm{C} 18$ reverse phase column (Agilent Eclipse XDB-C18 silica, $5 \mu \mathrm{m}, 4.6 \times 150 \mathrm{~mm}$; Agilent, Santa Clara, CA, U.S.A.) and was eluted with a linear gradient of $10 \%$ (vol/ vol) acetonitrile in water to $100 \%$ acetonitrile in $30 \mathrm{~min}$ at a flow rate of $1 \mathrm{ml} / \mathrm{min}$. The eluant was monitored at $210 \mathrm{~nm}$.

\section{Gene disruption.}

To disrupt DEP5 (AbPKS9) by the LME method (Cho et al. 2006), two primers were designed, one at the 954-bp position (in relation to the start codon) with an added HindIII enzyme site and the other at the 1,442-bp position with an added XbaI site (Fig. 2; Supplementary Table S1, for all primer sequences). These primers were used to amplify a 509-bp fragment from genomic DNA. PCR products were digested with HindIII and $X b a \mathrm{I}$ and were ligated to the corresponding sites in pCB1636 (Sweigard et al. 1997). The ligation was transformed into Escherichia coli DH5 $\alpha$ (Invitrogen, Carlsbad, CA, U.S.A.). The plasmid was isolated and used as template for PCR amplification, using M13 forward and M13 reverse primers. The PCR product was purified and concentrated to $1 \mu \mathrm{g} / \mu \mathrm{l}$.

To disrupt DEP6, DEP2, and DEP4 by the LME method, two primers for each gene (DEP6KOFor and DEP6KORev for DEP6, DEP2KOFor and DEP2KORev for DEP2, and DEP4KOFor and DEP4KORev for DEP4) were used to amplify 751-bp partial $D E P 6,812$-bp partial $D E P 2$, and 807-bp partial $D E P 2$ sequences from genomic DNA. Another set of two primers for each was used to amplify cassettes of $h p h l$ (encoding hygromycin phosphotransferase) from the plasmid pCB1636, i.e., DEP6HygFor and DEP6HygRev, DEP2HygFor and DEP2HygRev, or DEP4HygFor and DEP4HygRev. The resulting fragments for each gene were mixed and subjected to a second PCR reaction with primers DEP6KOFor and DEP6HygRev, DEP2KOFor and DEP2HygRev, or DEP4KOFor and DEP4HygRev. The resulting final products were used to transform A. brassicicola to make dep6, dep2, or dep4 mutants, respectively.

In order to complement the dep5 mutant, the wild-type DEP5 allele from $A$. brassicicola genomic DNA was amplified using primer set $\mathrm{P} 9 \mathrm{comF}$ and $\mathrm{P} 9$ comR. To complement the dep6, dep2, and dep4 mutants, a 2.7-kb DEP6 allele with primers TfcomF and TfcomR, a 2.6-kb DEP2 allele with primers MolcomF and MolcomR, and a 3.4-kb DEP4 allele with primers Mo2comF and Mo2comR were amplified from genomic DNA. Separately, a 1,449-bp nourseothricin resistance (NAT) cassette carrying the nourseothricin acetyltransferaseencoding gene natl was amplified using primer set PNRcomF and PNRcomR from plasmid pNR1 (Malonek et al. 2004). The final two PCR products, each target gene fragment, and a NAT cassette were used to transform simultaneously the dep2, dep4, or dep6 mutant strains, and transformants were selected on PDA plates containing nourseothricin. All transformants were subjected to two rounds of single-spore isolation.

For disruption by gene replacement, primer pairs 1 and 2 were used to amplify 575- and 476-bp fragments from the 5' and $3^{\prime}$ ends of DEP5, respectively, overlapping the transcriptional start and stop sites (Fig. 2). Primer pairs 4 and 5 were used to amplify 476- and 507-bp fragments of DEP6. The internal primers included an additional 25 to $30 \mathrm{bp}$ complementary to $h p h l$ of pCB 1003 (Carroll et al. 1994). Primers 7 and 8 were used to amplify $h p h l$ and included an additional 25 bp complementary to the target gene. The up- and downstream flanking regions of DEP5 and DEP6 were combined with $h p h 1$ in a second round of PCR, using the outside gene primers.

PCR products were ligated into pGem T-easy (Promega, Madison, WI, U.S.A.) and were transformed into E. coli DH5 $\alpha$ (Invitrogen). PCR products were purified with the QIAquick PCR purification kit (Qiagen, Valencia, CA, U.S.A.) and were used directly in transformation of protoplasts (Cho et al. 2006). Transformants were purified by two rounds of singlespore isolation.

\section{DNA extraction and analysis.}

DNA isolation and blotting were performed as described previously (Kim et al. 2007). The DNA blots shown in Figure $3 \mathrm{~B}$ were performed and hybridized according to the manufacturer's instructions (Roche Diagnostics, Mannheim, Germany), using digoxigenin (DIG)-labeled DNA probes. A total of 2 to 3 $\mu \mathrm{g}$ of genomic DNA was digested with EcoRI for analysis of DEP5 (AbPKS9), with XhoI and BamHI for analysis of DEP6, with PstI for analysis of $D E P 2$, and with BamHI for analysis of DEP4. The PCR DIG probe synthesis kit (Roche, Nutley, NJ, U.S.A.) was used to label a 509-bp fragment of DEP5, a 751-bp fragment of $D E P 6$, an 812-bp fragment of $D E P 2$, and an 807-bp fragment of DEP4. A 500-bp fragment from pCB1636 and a 1-kb fragment from pNR1 were used as probes for the selectable marker genes.

For the DNA blots shown in Figure 4, DNA was extracted from lyophilized mycelial mats of 5- to 7-day-old A. brassicicola MUCL 20297 grown in PDB in still culture (Pitkin et al. 1996). DNA $(15 \mu \mathrm{g})$ was digested with $N r u \mathrm{I}$ (dep5 mutants) or MluI (dep6 mutants) (Fig. 2B and C). DNA was transferred to Nytran SPC (Whatman, Maidstone, England) and was hybridized with ${ }^{32} \mathrm{P}$ probes (Pitkin et al. 1996).

RNA was extracted as described (Hallen et al. 2007). RTPCR followed by 5' and 3' RACE was done with the SMART RACE cDNA amplification kit (Clontech, Mountain View, CA, U.S.A.). Overlapping gene-specific primers were designed from available genomic sequence. In most cases, several genespecific primers were utilized. PCR products were cloned into pGem T-easy (Promega) and were transformed into E. coli DH5 $\alpha$ (Invitrogen).

For RNA blotting, 15 to $20 \mu \mathrm{g}$ of total RNA was used per lane. Internal gene-specific probes were generated directly from cDNA templates. rRNA bands on the blots were stained with $0.02 \%$ methylene blue in $0.5 \mathrm{M}$ sodium acetate, $\mathrm{pH} 5.5$.

\section{Virulence assays.}

Pathogenicity assays used wild-type and mutant strains of ATCC 96836. Conidia were harvested from PDA plates incubated for 7 days at $25^{\circ} \mathrm{C}$ and suspended in sterile water at $2 \times$ $10^{4}$ conidia per milliliter. Conidial suspensions $(10 \mu \mathrm{l})$ were applied as drops on the surface of leaves at the fifth through sixth leaf stages. Inoculated plants were placed in a plastic box at room temperature $\left(21^{\circ} \mathrm{C}\right)$ and were kept at $100 \%$ relative humidity for $24 \mathrm{~h}$ in the dark, followed by 4 days under fluorescent lights with a 16-h light and 8-h dark photoperiod. Lesion diameters were measured. The experiments were repeated four times with more than 15 plants per treatment. Results were analyzed using a pair-wise $t$-test using JMP (SAS, Cary, NC, U.S.A.).

Arabidopsis plants (Col-0 and pad3) were grown in a growth chamber at $20^{\circ} \mathrm{C}, 70 \%$ relative humidity, and a 12-hr light and dark cycle. A. brassicicola spores were collected from PDA culture plates in $2 \mathrm{ml}$ of $0.1 \%$ Tween-20. The third through the seventh true leaves from 4-week-old plants were spot-inoculated with $10 \mu \mathrm{l}$ of inoculum concentrated at $10^{5}$ spores per milliliter. Plants were covered to maintain high humidity. Lesions were measured and photographed 4 days after inoculation.

\section{ACKNOWLEDGMENTS}

We thank B. Thomma for MUCL 20297 and D. Jones and L. Chen of the Michigan State University Mass Spectrometry Facility for analysis of depudecin. This work was supported by award DE-FG02-91ER20021 
from the Chemical Sciences, Geosciences and Biosciences Division, Office of Basic Energy Sciences, Office of Science, U.S. Department of Energy (J. D. Walton), by the Virginia Bioinformatics Institute, National Science Foundation award number DBI-0443991, and the National Research Initiative of the United States Department of Agriculture Cooperative State Research, Education and Extension Service, grant number 2004-3560015030 (C. B. Lawrence).

\section{LITERATURE CITED}

Amnuaykanjanasin, A., Punya, J., Paungmoung, P., Rungrod, A., Tachaleat, A., Pongpattanakitshote, S., Cheevadhanarak, S., and Tanticharoen, M. 2005. Diversity of type I polyketide synthase genes in the wood-decay fungus Xylaria sp. BCC 1067. FEMS (Fed. Eur. Microbiol. Soc.) Microbiol. Lett. 251:125-136.

Brandl, A., Heinzel, T., and Krämer, O. H. 2009. Histone deacetylases: Salesmen and customers in the post-translational modification market. Biol. Cell 101:193-205.

Brosch, G., Ransom, R.. Lechner, T., Walton, J. D., and Loidl, P. 1995. Inhibition of maize histone deacetylase by HC-toxin, the host-selective toxin of Cochliobolus carbonum. Plant Cell 7:1941-1950.

Carroll, A. M., Sweigard, J. A., and Valent, B. 1994. Improved vectors for selecting resistance to hygromycin. Fungal Genet. Newslett. 41:22.

Cho, Y., Davis, J. W., Kim, K.-H., Wang, J., Sun, Q.-H., Cramer, R. A., Jr., and Lawrence, C. B. 2006. A high throughput targeted gene disruption method for Alternaria brassicicola functional genomics using linear minimal element (LME) constructs. Mol. Plant-Microbe Interact. 19:7-15.

Colonna, S., Gaggero, N., Carrea, G., Ottolina, G., Pasta, P., and Zambianchi, F. 2002. First asymmetric epoxidation catalysed by cyclohexanone monooxygenase. Tetrahedron Lett. 43:1797-1799.

Cramer, R. A., and Lawrence, C. B. 2004. Identification of Alternaria brassicicola genes expressed in planta during pathogenesis of Arabidopsis thaliana. Fungal Genet. Biol. 41:115-128.

Darkin-Rattray, S. J., Gurnett, A. M., Myers, R. W., Dulski, P. M., Crumley, T. M., Allocco, J. J., Cannova, C., Meinke, P. T., Colletti, S. L., Bednarek, M. A., Singh, S. B., Goetz, M. A., Dombrowski, A. W., Polishook, J. D., and Schmatz, D. M. 1996. Apicidin: A novel antiprotozoal agent that inhibits parasite histone deacetylase. Proc. Natl. Acad. Sci. U.S.A. 93:13143-13147.

Deubzer, H. E., Ehemann, V., Kulozik, A. E., Westermann, F., Savelyeva, L., Kopp-Schneider, A., Riester, D., Schwab, M., and Witt, O. 2008. Anti-neuroblastoma activity of Helminthosporium carbonum (HC)toxin is superior to that of other differentiating compounds in vitro. Cancer Lett. 8:21-28.

Devoto, A., Nieto-Rostro, M., Xie, D., Ellis, C., Harmston, R., Patrick, E., Davis, J., Sherratt, L., Coleman, M., and Turner, J. G. 2002. COI1 links jasmonate signalling and fertility to the SCF ubiquitin-ligase complex in Arabidopsis. Plant J. 32:457-466.

Dhawan, R., Luo, H., Foerster, A. M., AbuQamar, S., Du, H.-N., Briggs, S. D., Scheid, O. M., and Mengiste, T. 2009. HISTONE MONOUBIQUITINATION1 interacts with a subunit of the mediator complex and regulates the defense against nectrotrophic fungal pathogens in Arabidopsis. Plant Cell. 21:1000-1019.

Friesen, T. L., Faris, J. D., Solomon, P. S., and Oliver, R. P. 2008. Hostspecific toxins: Effectors of necrotrophic pathogenicity. Cell Microbiol. 10:1421-1428.

Gendler, K., Paulsen, T., and Napoli, C. 2008. ChromDB: The chromatin database. Nucleic Acids Res. 36:D298-302.

Haberland, M., Montgomery, R. L., and Olson, E. N. 2009. The many roles of histone deacetylases in development and physiology: Implications for disease and therapy. Nat. Rev. Genet. 10:32-42.

Hallen, H. E., Huebner, M., Shiu, S. H., Güldener, U., and Trail, F. 2007. Gene expression shifts during perithecium development in Gibberella zeae (anamorph Fusarium graminearum), with particular emphasis on ion transport proteins. Fung. Genet Biol. 44:1146-1156.

Hammock, L. G., Hammock, B. D., and Casida, J. E. 1974. Detection and analysis of epoxides with 4-(p-nitrobenzyl)-pyridine. Bull. Environ. Contam. Toxicol. 12:759-764.

Hendrickson, L., Davis, C. R., Roach, C., Nguyen, D. K., Aldrich, T., McAda, P. C., and Reeves, C. D. 1999. Lovastatin biosynthesis in Aspergillus terreus: Characterization of blocked mutants, enzyme activities and a multifunctional polyketide synthase gene. Chem. Biol. 6:429-439.

Hollender, C., and Liu, Z. 2009. Histone deacetylase genes in Arabidopsis development. J. Integ. Plant Biol. 50:875-885.

Jang, I. C., Pahk, Y. M., Song, S. I., Kwon, H. J., Nahm, B.H., and Kim, J. K. 2003. Structure and expression of the rice class-I type histone deacetylase genes OsHDAC1-3: OsHDAC1 overexpression in transgenic plants leads to increased growth rate and altered architecture. Plant J. 33:531-541.
Jenuwein, T., and Allis, C. D. 2001. Translating the histone code. Science 293:1074-1080.

Johal, G. S., Briggs, S. P. 1992. Reductase activity encoded by the $H M 1$ disease resistance gene in maize. Science 258:985-987.

Joung, K. E., Kim, D. K., and Sheen, Y.Y. 2004. Antiproliferative effect of trichostatin A and HC-toxin in T47D human breast cancer cells. Arch. Pharm. Res. 27:640-645.

Kagan, I. A., and Hammerschmidt, R. 2002. Arabidopsis ecotype variability in camalexin production and reaction to infection by Alternaria brassicicola. J. Chem. Ecol. 28:2121-2140.

Kim, K.-C., Lai, Z., Fan, B., and Chen, Z. 2008. Arabidopsis WRKY38 and WRKY62 transcription factors interact with histone deacetylase 19 in basal defense. Plant Cell 20:2357-2371.

Kim, K. H., Cho, Y., La Rota, M., Cramer, R. A., Jr., and Lawrence, C. B. 2007. Functional analysis of the Alternaria brassicicola non-ribosomal peptide synthetase gene AbNPS2 reveals a role in conidial cell wall construction. Mol. Plant Pathol. 8:23-39.

Kwon, H. J., Owa, T., Hassig, C. A., Shimada, J., and Schreiber, S. L. 1998. Depudecin induces morphological reversion of transformed fibroblasts via the inhibition of histone deacetylase. Proc. Natl. Acad. Sci. U.S.A. 95:3356-3361.

Kwon, H. J., Kim, J. H., Kim, M., Lee, J. K., Hwang, W. S., and Kim, D.Y. 2003. Anti-parasitic activity of depudecin on Neospora caninum via the inhibition of histone deacetylase. Vet. Parasitol. 112:269-276.

Malonek, S., Rojas, M. C., Hedden, P., Gaskin, P., Hopkins, P., and Tudzynski, B. 2004. The NADPH-cytochrome P450 reductase gene from Gibberella fujikuroi is essential for gibberellin biosynthesis. J. Biol. Chem. 279:25075-25084.

Matsumoto, M., Matsutani, S., Sugita, K., Yoshida, H., Hayashi, F., Terui, Y., Nakai, H., Uotani, N., Kawamura, Y., Matsumoto, K., et al. 1992. Depudecin: A novel compound inducing the flat phenotype of NIH3T3 cells doubly transformed by ras- and src-oncogene, produced by Alternaria brassicicola. J. Antibiot. (Tokyo) 45:879-885.

Meeley, R. B., Johal, G. S., Briggs S. P., and Walton, J. D. 1992. A biochemical phenotype for a disease resistance gene of maize. Plant Cell 4:71-77.

Mengiste, T., Chen, X., Salmeron, J., and Dietrich, R. 2003. The BOTRYTIS SUSCEPTIBLE1 gene encodes an R2R3MYB transcription factor protein that is required for biotic and abiotic stress responses in Arabidopsis. Plant Cell 15:2551-2565.

Monneret, C. 2005. Histone deacetylase inhibitors. Eur. J. Med. Chem. 40:1-13.

Multani, D. S., Meeley, R. B., Paterson, A. H., Gray, J., Briggs, S. P., and Johal, G. S. 1998. Plant-pathogen microevolution: Molecular basis for the origin of a fungal disease in maize. Proc. Natl. Acad. Sci. U.S.A. 95:1686-1691.

Narusaka, Y., Narusaka, M., Seki, M., Ishida, J., Nakashima, M., Kamiya, A., Enju, A., Sakurai, T., Satoh, M., Kobayashi, M., Tosa, Y., Park, P., and Shinozaki, K. 2003. The cDNA microarray analysis using an Arabidopsis pad 3 mutant reveals the expression profiles and classification of genes induced by Alternaria brassicicola attack. Plant Cell Physiol. 44:377-387.

Navarro, L., Bari, R., Achard, P., Lisón, P., Nemri, A., Harberd, N. P., and Jones, J. D. 2008. DELLAs control plant immune responses by modulating the balance of jasmonic acid and salicylic acid signaling. Curr. Biol. 18:650-655.

Oh, I. S., Park, A. R., Bae, M. S., Kwon, S. J., Kim, Y. S., Lee, J. E., Kang, N. Y., Lee, S., Cheong, H., and Park, O. K. 2005. Secretome analysis reveals an Arabidopsis lipase involved in defense against Alternaria brassicicola. Plant Cell 17:2832-2847.

Oikawa, T., Onozawa, C., Inose, M., and Sasaki, M. 1995. Depudecin, a microbial metabolite containing two epoxide groups, exhibits antiangiogenic activity in vivo. Biol. Pharm. Bull. 18:1305-1307.

Pedley, K. F., and Walton, J. D. 2001. Regulation of cyclic peptide biosynthesis in a plant pathogenic fungus by a novel transcription factor. Proc. Natl. Acad. Sci. U.S.A. 98:14174-14179.

Pitkin, J. W., Panaccione, D. G., and Walton, J. D. 1996. A putative cyclic peptide efflux pump encoded by the TOXA gene of the plant-pathogenic fungus Cochliobolus carbonum. Microbiology 142:1557-1565.

Ransom, R. F., and Walton, J. D. 1997. Histone hyperacetylation in maize in response to treatment with HC-toxin or infection by the filamentous fungus Cochliobolus carbonum. Plant Physiol. 115:1021-1027.

Rossi, V., Locatelli, S., Varotto, S., Donn, G., Pirona, R., Henderson, D.A., Hartings, H., and Motto, M. 2007. Maize histone deacetylase hda101 is involved in plant development, gene transcription, and sequence-specific modulation of histone modification of genes and repeats. Plant Cell 19:1145-1162.

Schenk, P. M., Kazan, K., Manners, J. M., Anderson, J.P., Simpson, R. S., Wilson, I. W., Somerville, S. C., and Maclean, D. J. 2003. Systemic gene expression in Arabidopsis during an incompatible interaction with 
Alternaria brassicicola. Plant Physiol. 132:999-1010.

Sindhu, A., Chintamanani, S., Brandt, A. S., Zanis, M., Scofield, S. R. Johal, G. S. 2008. A guardian of grasses: Specific origin and conservation of a unique disease-resistance gene in the grass lineage. Proc. Natl. Acad. Sci. U.S.A. 105:1762-1767.

Staal, J., Kaliff, M., Dewaele, E., Persson, M., and Dixelius, C. 2008 $R L M 3$, a TIR domain encoding gene involved in broad-range immunity of Arabidopsis to necrotrophic fungal pathogens. Plant J. 55:188-200.

Sweigard, J., Chumley, F., Carroll, A., Farrall, L., and Valent, B. 1997. A series of vectors for fungal transformation. Fungal Gen. Newsl. 44:5253.

Tanaka, M., Fujimori, T., and Nabeta, K. 2000. Biosynthesis of depudecin, a metabolite of Nimbya scirpicola. Biosci. Biotechnol. Biochem. 64:244247.

Thines, B., Katsir, L., Melotto, M., Niu, Y., Mandaokar, A., Liu, G., Nomura, K., He, S. Y., Howe, G. A., and Browse, J. 2007. JAZ repressor proteins are targets of the $\mathrm{SCF}(\mathrm{COI} 1)$ complex during jasmonate signalling. Nature 448:661-665.

Tian, L., and Chen, Z. J. 2001. Blocking histone deacetylation in Arabidopsis induces pleiotropic effects on plant gene regulation and development. Proc. Natl. Acad. Sci. U.S.A. 98:200-205.

Thomma, B. P. H. J., Nelissen, I., Eggermont, K., and Broekaert, W. F. 1999. Deficiency in phytoalexin production causes enhanced susceptibility of Arabidopsis thaliana to the fungus Alternaria brassicicola. Plant J. 19:163-171.

van Berkel, W. J. H., Kamerbeek, N. M., and Fraaiji, M. W. 2006. Flavoprotein monooxygenases, a diverse class of oxidative biocatalysts. J. Biotechol. 124:670-689.

van Wees, S. C. M., Chang, H.-S., Zhu, T., and Glazebrook, J. 2003. Characterization of the early response of Arabidopsis to Alternaria brassicicola infection using expression profiling. Plant Physiol. 132:606-617.

Veronese, P., Chen, X., Bluhm, B., Salmeron, J., Dietrich, R., and
Mengiste, T. 2004. The BOS loci of Arabidopsis are required for resistance to Botrytis cinerea infection. Plant J. 40:558-574.

Walton, J. D. 1996. Host-selective toxins: Agents of compatibility. Plant Cell 8:1723-1733.

Walton, J. D. 2006. HC-toxin. Phytochemistry 67:1406-1413.

Walton, J. D., and Panaccione, D. G. 1993. Host-selective toxins and disease specificity: Perspectives and progress. Annu. Rev. Phytopathol. 31:275-303.

Westerheide, S. D., Anckar, J., Stevens, S. M., Jr., Sistonen, L., and Morimoto, R. I. 2009. Stress-inducible regulation of heast shock factor 1 by the deacetylase SIRT1. Science 323:1063-1066.

Wu, K., Malik, K., Tian, L., Brown, D., and Miki, B. 2000. Functional analysis of a RPD3 histone deacetylase homolog in Arabidopsis thaliana. Plant Mol. Biol. 44:167-176.

Wu, K., Tian, L., Zhou, C., Brown, D., and Miki, B. 2003. Repression of gene expression by Arabidopsis HD2 histone deacetylases. Plant J. 34:241-247.

Young, C., McMillan, L., Telfer, E., and Scott, B. 2001. Molecular cloning and genetic analysis of an indole-diterpene gene cluster from Penicillium paxilli. Mol. Microbiol. 39:754-764.

Zhang, S., Monahan, B. J., Tkacz, J. S., and Scott, B. 2004. Indole-diterpene gene cluster from Aspergillus flavus. Appl. Environ. Microbiol. 70:6875-6883.

Zhou, C., Zhang, L., Duan, J., Miki, B., and Wu, K. 2005. HISTONE DEACETYLASE19 is involved in jasmonic acid and ethylene signaling of pathogen response in Arabidopsis. Plant Cell 17:1196-1204.

\section{AUTHOR-RECOMMENDED INTERNET RESOURCES}

FGENESH: www.softberry.com

Virginia Bioinformatics Institute: www.alternaria.org 